\title{
Editorial
}

Public Administration and Policy - An Asia-Pacific Journal (PAP) was first launched and jointly published by HKPAA and City University of Hong Kong in 1992. It was suspended in 2005 and re-launched in 2012 with the new co-publisher, the School of Professional Education and Executive Development (SPEED) of The Hong Kong Polytechnic University. Since 2018, it has been published online in open access on the Emerald Insight Platform. This year marks the $30^{\text {th }}$ anniversary of its first launch and the $10^{\text {th }}$ anniversary of the re-launch and the $4^{\text {th }}$ anniversary of online publication with Emerald.

PAP now publishes three issues with over twenty articles per year. It is indexed and abstracted by Emerging Sources Citation Index (ESCI), CrossRef, EBSCO Discovery Service, Google Scholar, Health Research Premium Collection (ProQuest), Healthcare Administration Database (ProQuest), ProQuest Central, ProQuest Central Basic (Korea), ProQuest Central Essentials, ProQuest Central Student, Publicly Available Content Database (ProQuest), Summons (ProQuest) and WorldCat. Academics and practitioners in public administration, management, public policy, and related fields are welcomed to contribute papers to PAP.

The COVID-19 was declared as pandemic by the World Health Organization in March 2020 and it has infected more than 243 million people and caused the death of close to 5 million people worldwide as of October 2021 (Worldometer, 2021). Currently, a wide range of countries are still under the threat of the deadly coronavirus especially with the spread of the variants, whereas only very few countries have it under control through stringent quarantine measures and vaccinations. Wearing mask is an effective way of preventing the infection of COVID-19 which is well documented in the literature. An article in this issue will illustrate the value of wearing mask by example from the findings in the U.S. that implemented the mandatory mask wearing before 30 September 2020. Moreover, the coronavirus pandemic has caused significant turbulences and downturn in the world economy. Another article in this issue analyses the global economic cost of the pandemic and sheds lights on four key aspects which have been significantly affected and proposes how organizations can survive based on contingency theory.

Hong Kong has experienced a very serious social and political unrest in 2019. On 30 June 2020, China's National People's Congress passed the National Security Law in the Hong Kong Special Administrative Region (HKSAR) with the aim of stopping violence and the riots in Hong Kong. The National Security Law prohibits and punishes the crimes of secession, subversion, terrorist activities, and collusion with foreign countries or external forces to endanger national security (Hong Kong Special Administrative Region, 2020). The Law is considered as an important tool to restore the stability of Hong Kong politically. An article in this issue discusses the political and social effects on the governance of HKSAR. In the past year and half, Hong Kong's social and political unrests have largely been stopped. However, the economic and business sectors are still severely affected by the COVID-19 pandemic and it might take another year before a full economic recovery can be seen.

(c) Peter K.W. Fong. Published in Public Administration and Policy. Published by Emerald Publishing Limited. This article is published under the Creative Commons Attribution (CC BY 4.0) licence. Anyone may reproduce, distribute, translate and create derivative works of this article (for both commercial and non-commercial purposes), subject to full attribution to the original publication and authors. The full terms of this licence may be seen at http://creativecommons.org/licences/by/4.0/legalcode

Public Administration and Policy Vol. 24 No. 3,2021 pp. $230-233$ 


\section{Summary of articles}

This third issue of 2021 consists of eight articles with two related to the above mentioned coronavirus pandemic, three on the Hong Kong and China political, legal and social contexts, one comparative analysis of China and Singapore's political leaders, one on India's economic revitalization programme, and one on Ghana's healthcare service respectively. A brief introduction of these articles is given below.

The first article on "The National Security Law: political and social effects on the governance of the Hong Kong Special Administrative Region" by Siu-kai Lau identifies the major political and social effects of the Law after its enactment on 1 July 2020 in Hong Kong. It is argued that such enactment has allowed Hong Kong not only to end its protracted political turmoil since its return to China in 1997, but will also generate the favorable conditions for long-term stability and effective governance in the territory. Specifically, it summarized that the Law has brought about significant changes in the political psychology of Hongkongers, the balance of power among different political forces, the ability of external forces to interfere in Hong Kong politics, the way Hong Kong is governed, the relationship between the government and the legislature, the activities in the educational and cultural sectors, and the behavior of the judiciary. This article would be of interest to scholars and people who are interested in the implementation of "One Country, Two Systems" in the HKSAR as well as Beijing's new policy towards Hong Kong in the aftermath of Hong Kong's unprecedented riots and violence.

The second article is "Upholding parental responsibility by family mediation - revisiting the role of the law for children in divorce in Hong Kong" by Sau-wai Law. Based on policies and documents reviews, and literal analysis of court guidance, this paper analyses the different contents and requirements of Practice Direction 15.10 (the process of family mediation) and Practice Direction 31 (the process of general mediation), evaluates their impact, and highlights the need to incorporate the spirit of family mediation into legislation to better protect children's interest in a family dispute. In an effort to promote parental responsibility-based negotiation in divorce proceeding, a missed opportunity in enacting the Children Proceedings (Parental Responsibility) Bill in 2015 might be a blessing in disguise as it offers another chance for policy makers to consider how to direct parties to negotiate and communicate, to seek and benefit from professional guidance on a continuous basis, and to seek alternative channels to resolve disputes other than the court room. The paper advocates a switch from a "rights-based" to "responsibility-based" approach in handling children's matters should be revisited by incorporating the spirit of family mediation into legislation.

The third article on "The Guangdong-Hong Kong nexus in grassroots collective actions amid Sino-Anglo interface, 1841 to 1927 " by Kent Wan provides an analysis of the historical linkages between Chinese on both sides of the Sino-Hong Kong border during this period by examining important incidents of collective actions in the colony and Canton. Based on annual reports of the colonial administration in Hong Kong, especially those witnessed major incidents of anti-colonial agitations, this paper analyzes how British policymakers were confronted by collective actions mounted by Chinese in Canton and Hong Kong. This paper examines if a Cantonese regional solidarity served as the foundation for popular movements, which in turn consolidated a rising Chinese nationalism when Canton and Hong Kong were the focal points of mass actions against imperialism. It reveals that Hong Kong Chinese workers were vanguards of the modern Chinese revolutions that transformed not just their homeland, but their lives, allegiances, and aspirations as Chinese in a domain under foreign jurisdiction on Chinese soil, as their actions were emulated by their compatriots outside of South China, thus starting a chain reaction that culminated in the establishment of the Nanjing regime.

The fourth article on "How to select good leaders in Asian countries: the case of China and Singapore" by Franky K.H. Choi gives an analytical account of the ways adopted by the two 
PAP

24,3

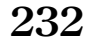

Asian political leaders, Deng Xiaoping of China and Lee Kuan Yew of Singapore, in selecting their successors. Based on comparative historical analysis, as to the duo's succession results, Deng Xiaoping's selection of leaders was somewhat successful, while Lee Kuan Yew's was phenomenal. This indicates that good leaders could still be selected beyond universal suffrage, mainly because of the elites-driven context in both cases. It concludes that the means of selecting elites with the abilities and qualities defined by these political strongmen are lessons for countries practising Western-style democracy. Learning from the duo's leadership successions, the West may treat elite politics as the supplement under Western Electoral Democracies in order to avoid their countries falling into the trap of populism. The West could consider the exceptional criteria prized by the duo for leadership successions. Considering such interactions among elites in the real-life context, it could serve as an alternative model to Western-style democracy.

The fifth article is "A study of the effect of wearing face masks in preventing COVID-19 transmission in the United States of America" by Kazuyuki Suzuki, Tomonori Hasegawa, Noriaki Kano and Yoshihisa Okamoto. The article demonstrates the effectiveness of face mask wearing as a means to prevent COVID-19 transmission in U.S. The findings revealed that for the 50 U.S. states and Washington, D.C. that implemented the mask mandates before 30 September 2020, the higher the mask wearing rate, the lower the number of COVID-19 cases. For the 23 states with mobility reduction of less than 15 percent, the higher the proportion of population required to wear masks, the lower the number of cases. The positive effect of wearing masks is shown based on simple descriptive statistics for intuitive and intelligible understanding, which may lead people to comprehend the importance of wearing masks, and break through their custom, culture, and norms, and wear masks. Through understanding the benefits of wearing masks, it is hoped to facilitate the change of societal behavior and more people are willing to wear face mask.

The sixth article is "The global economic cost of coronavirus pandemic: current and future implications" by Mian M. Ajmal, Mehmood Khan and Muhammad Kashif Shad. The prolonged movement control orders, social distancing, and lockdowns under the coronavirus pandemic have triggered global economic downturn, disrupted the demand and supply chains, and caused many jobs loss. This article summarizes that the world has witnessed farranging economic consequences in four aspects: (i) decline in personal consumption; (ii) decline in the investments and stock prices in capital market; (iii) decline in government spending in developmental projects and increase in new borrowing; and (iv) decline of exports of goods to international markets. Based on contingency theory, the article suggests the need for urgent actions by the world leaders to oversee, anticipate, and manage the risks and cushion the economic consequences. It concludes that the flexibility and adaptability of leaders, effectiveness, workforce protection, efficient use of modern technology, including automation and artificial intelligence, would enhance the resilience of supply chains which will support organizations to sustain in this critical time.

The seventh article is "Impact of an economic revitalization programme on export and employment generation: a case study of One District One Product Programme in Uttar Pradesh, India" by Aditya P. Tripathi and Noopur Agrawal. This paper discusses the role of the economic revitalization programme, One District One Product (ODOP) implemented in the state of Uttar Pradesh of India in 2018, examine its strategy, and analyze its impact on employment generation, export promotion and economic growth of the state. Based on case study approach, this article illustrates the positive impact of the systematically crafted ODOP programme. Nevertheless, for desired success, it signifies the inevitability of active participation and engagement of public that has always been a precarious subject in the literature of public administration and governance. The motive-approach matrix offers a guiding live example for other states/countries to successfully implement ODOP programme which is a transformational step for realizing the true potential of each district. Strategies like 
ODOP may serve as an agent of change and be of immense help to governments in solving the problems of economic inequalities and regional imbalances.

The last article "Quality healthcare services under National Health Insurance Scheme in Ghana: perspectives of health policy implementers and beneficiaries" by Daniel Dramani Kipo-Sunyehzi examines the factors that affect the quality of healthcare services in the implementation of the National Health Insurance Scheme (NHIS) at the local level in Ghana from the perspectives of health policy implementers and beneficiaries in public-private organisations. By adopting a mixed research method with both over 100 participants took part in the interviews and the questionnaire survey, the study found that from the implementers' perspectives, these factors greatly affect the quality of healthcare services referrals, effectiveness in monitoring, timeliness, efficiency, reimbursement, compliance with standard guidelines of Ghana Health Service (GHS) and accreditation process. For the beneficiaries, three factors are important, including medical consultations, diagnostic services and the supply of drugs and medicines. The study found that implementers and beneficiaries exhibited a mixed reaction on accessing some healthcare services as where the implementers perceived that beneficiaries have more access to such services, the beneficiaries think otherwise.

I wish to thank all the authors for contributing their papers to this issue and the reviewers for their critical but constructive comments in helping the authors to improve their papers. Finally, I thank Emerald and our editorial team as well as the members of both Asia Pacific Editorial Board and International Editorial Advisory Board for their contributions in making the successful publication of this issue possible. We hope these papers will enhance the understanding of various issues on public administration and policy across the regions.

\section{Peter K.W. Fong \\ Editor-in-Chief, PAP Journal \\ President, Hong Kong Public Administration Association}

\section{About the Editor-in-Chief}

Professor Peter K.W. Fong, PhD (New York University), is President of Hong Kong Public Administration Association and Editor-in-Chief of PAP Journal. He teaches strategic management and supervises DBA students' dissertations of University of Wales TSD and lectures Public Policy Values and Ethics at the Chinese University of Hong Kong. He held Advisory/Visiting Professorships in Tongji, Tsinghua, Renmin, Tianjin Universities and HK Poly U. He has been members of HK Institute of Planners \& Planning Institute Australia. He was a Teaching Fellow of Judge Business School, University of Cambridge; Director of EMBA programme, HKU Business School; Associate Professor, Department of Urban Planning, HKU; Executive Vice President of City University of Macao; Honorary Professor, China Training Centre for Senior Civil Servants in Beijing; Studies Director, Civil Service Training \& Development Institute, HKSAR Government; Visiting Scholar, MIT; Director, Delta Asia Bank; Consultant, the World Bank. Peter K.W. Fong can be contacted at: fongpeter@netvigator.com

\section{References}

Hong Kong Special Administrative Region (2020), "The Law of the People's Republic of China on Safeguarding National Security in the Hong Kong Special Administrative Region”, available at: https://www.gld.gov.hk/egazette/pdf/20202448e/egn2020244872.pdf (accessed 20 October 2021).

Worldometer (2021), "COVID-19 Coronavirus pandemic”, available at: https://www.worldometers.info/ coronavirus/\#countries (accessed 22 October 2021). 